\title{
PROTECTION OF APPROPRIATE (BUSINESS) REPUTATION OF A LEGAL ENTITY IN THE LAW OF THE RUSSIAN FEDERATION AND THE UNITED STATES
}

\author{
Vladimir V. Yastrebov \\ Peoples' Friendship University of Russia, Moscow, Russian Federation
}

\begin{abstract}
Introduction: the business reputation of a legal entity characterizes it in a certain activity area and affects the competitiveness of the company, which determines the existence of the mechanisms for its protection in the law. For this purpose, the author compares the legislation of Russia and the United States in the field of regulating the protection of the business reputation of a legal entity, since the doctrine of defamation is more developed in the US law. Using the methods of scientific knowledge, first of all, the method of comparative analysis, the author reveals the advantages and disadvantages of the Russian legislation in the field of interest. Results: the author indicates that currently the concept of "business reputation" of a legal entity has a market economic (property) content, and therefore, considers the position of the Russian law enforcers on the existence of a link between the defamation in relation to the government agencies, other bodies, employees and the defamation in relation to the legal entity to be a positive trend, if the activities of these persons is associated with the legal entity's activities. Conclusions: the author concludes that it is necessary to consolidate in the Russian legislation the definition of "business reputation of a legal entity", the relationship between the defamation against the government agencies' members and ones of other bodies associated with their professional activities, and the damage to the business reputation of the legal entity. The US law is a well-developed effective tool for the protection against defamation, the limit of which is the constitutional right to freedom of speech; the Russian law is more protective of the personal interest, not the public one. This fundamental difference does not allow us to fully integrate some effective provisions of the American legislation into the Russian legislation.
\end{abstract}

Key words: business reputation, defamation, tort liability, market economy, legal entity, methods of protecting business reputation, intangible harm, moral harm.

Citation. Yastrebov V.V. Protection of Appropriate (Business) Reputation of a Legal Entity in the Law of the Russian Federation and the United States. Legal Concept, 2019, vol. 18, no. 2, pp. 117-121. (in Russian). DOI: https://doi.org/10.15688/lc.jvolsu.2019.2.19

\section{ЗАЩИТА ДОЛЖНОЙ (ДЕЛОВОЙ) РЕПУТАЦИИ ЮРИДИЧЕСКОГО ЛИЦА В ПРАВЕ РОССИИ И США}

\author{
Владимир Валерьевич Ястребов \\ Российский университет дружбы народов, г. Москва, Российская Федерация
}


российского правоприменителя о наличии связи между диффамацией в отношении органов управления, иных органов, работников и диффамации в отношении самого юридического лица, если деятельность данных лиц ассоциируется с деятельностью юридического лица. Выводы: автором сделан вывод о необходимости закрепления в российском законодательстве определения «деловая репутация юридического лица», связи между диффамацией в отношении членов органов управления и иных органов, связанных с их профессиональной деятельностью и ущербом деловой репутации самого юридического лица. Законодательство США является проработанным действенным инструментом для защиты от диффамации, пределом которой становится конституционное право на свободу слова, российское законодательство в большей степени защищает личный интерес, а не общественный. Данное принципиальное различие не позволяет в полной мере интегрировать в российское законодательство отдельные эффективные положения американского законодательства.

Ключевые слова: деловая репутация, диффамация, деликтная ответственность, рыночная экономика, юридическое лицо, способы защиты деловой репутации, нематериальный вред, моральный вред.

Цитирование. Ястребов В. В. Защита должной (деловой) репутации юридического лица в праве России и США // Legal Concept = Правовая парадигма. - 2019. - Т. 18, № 2. - C. 117-121. - DOI: https://doi.org/10.15688/ lc.jvolsu.2019.2.19

\section{Введение}

В условиях продолжающейся трансформации гражданско-правовой системы России проблема создания эффективного института права на должную репутацию нуждается в особо внимательном подходе со стороны судебной власти ввиду своей социальной значимости. Сравнительный анализ основных положений законодательства в данной области правового регулирования позволит выявить не только недостатки, но и достоинства российской законодательной базы, что соответственно предопределяет практическую ценность исследования.

Именно при разрешении дел о диффамации особенно важно достигнуть равновесия между правом юридического лица на защиту деловой репутации, с одной стороны, и правом членов общества на получение информации, свободой слова, свободой прессы - с другой. Слишком усердная защита чьей-либо деловой репутации может расцениваться как воспрепятствование свободному распространению информации, необходимой для общества, и следовательно посягательством на свободу слова как на важнейшее конституционное право. Наиболее проработанным с точки зрения баланса свободы слова и права на деловую репутацию считается американский институт защиты от диффамации, многие положения которого восприняты Европейским судом.

Термин «диффамация» отсутствует в российском гражданском праве, но употребляется активно в Постановлениях Европейс- кого суда и, соответственно, рассматривается российским правоприменителем аналогично понятию распространения порочащих сведений, не соответствующих действительности (ст. 152 ГК РФ) [4].

\section{Особенности механизма защиты}

\section{деловой репутации юридического лица \\ в законодательстве России и США}

Положительная деловая репутация юридического лица способствует воплощению целей организации, ради которой она была создана, она помогает держать юридическое лицо в тонусе и поддерживать конкурентоспособность. Создание положительной деловой репутации юридического лица - это, как правило, довольно длительный процесс, предполагающий значительные усилия как непосредственно исполнительных органов юридического лица, так и его учредителей и работников. Но ее можно достаточно быстро испортить антирекламой, целенаправленной дискредитацией со стороны конкурента и т. д. Верховный суд РФ выделяет предпринимателей, адвокатов, нотариусов, к которым относятся те же положения, что и к юридическим лицам [2].

В настоящее время правоприменитель четко определился в отношении компенсации морального вреда как способа защиты в случае диффамации в отношении юридического лица, предложив в качестве альтернативы «репутационный вред» [3]. Организация вправе подвергать сомнению и оспаривать в суде сведения, которые приносят вред репута- 
ции [9, с. 11]. В основном деловая репутация может быть испорчена путем вынесения неверной информации о работе юридического лица в средствах массовой информации. Распространение порочащих юридическое лицо сведений порождает факт длительной неопределенности, причиняющей юридическому лицу значительное неудобство [7].

Диффамация является гражданским правонарушением и влечет ответственность при соблюдении общих условий деликтной ответственности за исключением условия о вине ответчика [5].

Главным условием наступления ответственности за диффамацию является доказанность порочащего характера информации и факта ее распространения, также должен быть установлен факт сформированной деловой репутации истца и утраты доверия к его репутации, следствием чего может быть сокращение числа клиентов и утрата конкурентоспособности [5].

Необходимо отметить, что распространение порочащих его деловую репутацию сведений может быть осуществлено различными способами. В частности, юридическое лицо действует в гражданском обороте через свои исполнительные органы (ст. 53 ГК РФ), следовательно деловая репутация лиц, которые в них входят, оказывает влияние на деловую репутацию организации в целом (п. 12 Обзоpa), в виду этого действия и образ указанных лиц ассоциируются с этим юридическим лицом. Также репутация юридического лица отражается непосредственно на самом руководителе юридического лица [3]. В частности, как указывается в одном из судебных постановлений: «Сведения, относящиеся к руководству компании, распространяются на все предприятие в целом, даже если люди, о которых идет речь, остаются неназванными, в то время как их причастность к компании четко обозначается и не вызывает сомнений. В связи с этим можно прийти к выводу, что деловая репутация члена совета директоров тесно связана с деловой репутацией организации, а посягательство на нее влечет ущемление прав организации. То же самое касается и деловой репутации исполнительного органа, так как распространенные сведения о директоре относятся к деловой репутации общества [6].
При этом из содержания данной информации должна прослеживаться безусловная связь между организацией и лицом, упомянутым в таком сообщении, их отождествление. Ввиду того что на положительную деловую репутацию оказывают влияние и профессиональные, и деловые, и порой человеческие характеристики лиц, входящих в иные органы юридического лица (совет директоров (наблюдательный совет), ревизионная комиссия), целесообразно распространить вышеуказанную правоприменительную практику и на данных лиц. Особенно, если учесть, что судебная практика определила непосредственную связь между диффамацией в отношении работника и деловой репутацией юридического лица, с которым последний состоит в трудовых отношениях, так как распространение ложной информации о некачественном выполнении работником своей работы повлечет возможный отток клиентов.

По данной категории дел истец обязан доказать только то, что ответчик распространил порочащие сведения, а уже непосредственно ответчик должен предоставить доказательства того, что данные сведения соответствуют действительности. В отношении же юридических лиц должна быть установлена презумпция нарушения их деловой репутации, если из информации о недобросовестности лиц, входящих в органы юридического лица, работников, проявленной при выполнении ими производственно-хозяйственных функций, прослеживается четкая связь между этими лицами и (или) их действиями и самим юридическим лицом.

В праве США под диффамацией, как правило, понимают выявление неверных сведений, порочащих честь и достоинство лица или компании. Как утверждает американский юрист Роберт Вандерет: «Диффамация это утверждение, являющееся ложным и не защищенным привилегиями, порочащее репутацию человека, побуждая других людей осуждать или ненавидеть его или нанося ущерб бизнесу этого человека» [8, с. 43]. Ложные сведения и сведения, которые нанесли ущерб лицу, именуют дискредитирующими. В шестидесятых годах Верховный суд РФ отменил действие большинства нормативных актов, которые устанавливали непопулярность общественного мнения, именно это про- 
тиворечило положениям Конституции в сфере свободы прав. Поэтому споры о диффамации практически совсем ушли в гражданское право и рассматриваются в качестве дел частного обвинения.

Как упоминалось ранее, в случае возникновения диффамации в средствах массовой информации возрождается столкновение двух прав: на свободу слова и защиту чести, на достоинства и репутации. В связи с этим создание равновесия между этими правами представляется особенной характеристикой и порождает деление в научной доктрине и правоприменительной практике (не только в сфере мировой арены, но и в рамках национальных правовых систем). В ряде стран существуют различные подходы к данному вопросу. В США главную роль играет право на свободу слова, а также СМИ. Несмотря на тот факт что права Великобритании и США схожи по основным чертам, американские суды не брали во внимание решения судов Великобритании на том основании, что прослеживалось противоречие Первой поправке к Конституции США.

Также стоит отметить, что в США установлена обязанность, возлагающаяся именно на истца, доказать не только факт распространения сведений ответчиком, но и то, что их порочащий характер не соответствует действительности.

Корпорации и иные коммерческие организации могут подавать в суд только в случаях, когда диффамирующее заявление нанесло им ущерб в сфере осуществления ими бизнеса или лишило их деловых партнеров. При этом диффамирующее заявление, сделанное в отношении членов правления, служащих, акционеров корпорации, не является диффамацией корпорации. В связи с этим диффамацией корпорации может считаться только заявление, которое затрагивает осуществление корпорацией своей деятельности, не совместимой с надлежащим ведением бизнеса. Сведения, касающиеся качества выпускаемой продукции или ее прав на имущество, могут стать основанием для обращения в суд за так называемую «вредоносную фальсификацию»). Для профессии диффамацией считаются только сведения, которые несовместимы с профессией, обвинение в пьянстве или в других амо- ральных поступках не может повлиять на предпринимателя [10, с. 100].

\section{Выводы}

Таким образом, американское право подходит к диффамационному ущербу деловой репутации лица, в том числе и юридического лица, с позиций гражданско-правовой ответственности, требующей наличия вины, и тем самым определяет узкоспециализированный характер категории «деловая репутация». Общая же тенденция развития российской правовой доктрины направлена на построение категории «деловая репутация» именно с позиции универсальности последней. Американское право содержит исключительные юридические составы, позволяющие нивелировать осложнение доказывания репутационного ущерба путем установления случаев безвиновной ответственности в обозначенной сфеpe [1, с. 72], на которые не распространяется российское законодательство (так же, как и деления на общие и специальные репутационные убытки). В таких условиях неизбежное интегрирование только общей канвы теории в отечественное правовое поле порождает ситуацию продуцирования системных ошибок доктрины в рассматриваемой области и, как следствие, - формирование не отвечающей объективному социальному запросу судебной практики.

\section{СПИСОК ЛИТЕРАТУРЫ}

1. Маргольф, М. Е. Защита чести, достоинства и деловой репутации по американскому праву / М. Е. Маргольф, Ю. В. Холоденко // Юрислингвистика. - 2016. - № 5. - С. 72-79.

2. Определение Верховного Суда Российской Федерации от 26 октября 2015 г. по делу № 307-ЭС 155345, А56-17708/2014. - Доступ из справ.-правовой ситемы «КонсультантПлюс».

3. Обзор практики рассмотрения судами дел по спорам о защите чести, достоинства и деловой репутации (утв. Президиумом Верховного Суда РФ 16.03.2016) // Бюллетень Верховного Суда РФ. - 2016. № 10. - Доступ из справ.-правовой системы «КонсультантПлюс».

4. ПостановлениеПленума ВС РФ от 24.02.2005 г. № 3 «О судебной практике по делам о защите чести и достоинства граждан, а также деловой репутации 
граждан и юридических лиц». - Доступ из справ.правовой системы «КонсультантПлюс».

5. Постановление Президиума ВАС РФ от 17.07.2012 г. № 17528/11 по делу № А45-22134/2010. Доступ из справ.-правовой системы «КонсультантПлюс».

6. Постановление ФАС Уральского округа от 22 июня 2011 г. № Ф09-3347/11-С6 по делу № А6032756/2010-С7. - Доступ из справ.-правовой системы «КонсультантПлюс».

7. Постановление ЕСПЧ от 06.04.2000 г. «Дело “Комингерсолль С.A.” (Comingersoll S.A.) против Португалии» (жалоба № 35382/97). - Электрон. текстовые дан. - Режим доступа: http://www.echr.coe.in. - Загл. с экрана.

8. Самородов, Д. А. Понятие неприкосновенности чести и достоинства в законодательствах Великобритании, Франции, США, Германии и России / Д. А. Самородов // Вестник Московского университета им. С. Ю. Витте. Серия 2, Юридические науки. - 2016. - № 2 (9). - С. 40-47.

9. Саяпина, Е. Н. О защите деловой репутации / Е. Н. Саяпина // Актуальные вопросы бухгалтерского учета и налогообложения. - 2014. - № 4. C. $10-15$.

10. Rubenstein, Mitchel H. A Quick Look at the New York Defamation - Law. - Электрон. текстовые дан. Режим доступа: https://www researchgate.net. - Загл. с экрана.

\section{REFERENCES}

1. Margolf M.E., Kholodenko Yu.V. Protection of Honor, Dignity and Business Reputation in American Law. Law Firm, 2016, no. 5, pp. 72-79. (in Russian).

2. Determination of the Supreme Court of the Russian Federation of October 26, 2015 in Case № 307ЭC15-5345, A56-17708/2014. Access from Reference Legal System 'KonsultantPlyus'. (in Russian).
3. Review of the Practice of Consideration by Courts of Cases on Disputes about the Protection of Honor, Dignity and Business Reputation "(Approved by the Presidium of the Supreme Court of the Russian Federation on March 16, 2016). Bulletin of the Supreme Court of the Russian Federation, 2016, no. 10. Access from Reference Legal System 'KonsultantPlyus'. (in Russian).

4. Resolution of the Plenum of the Armed Forces of the Russian Federation of 24.02.2005, № 3 “On Judicial Practice in Cases of Protecting the Honor and Dignity of Citizens, as well as the Business Reputation of Citizens and Legal Entities". Access from Reference Legal System 'KonsultantPlyus'. (in Russian).

5. Resolution of the Presidium of the Supreme Court of Arbitration of the Russian Federation of 17.07.2012 № 17528/11 in Case № A45-22134/2010. Access from Reference Legal System 'KonsultantPlyus'. (in Russian).

6. Resolution of the Federal Antimonopoly Service of the Ural District of June 22, 2011 № F093347/11-C6 in Case № A60-32756/2010-C7. Access from Reference Legal System 'KonsultantPlyus'. (in Russian).

7. ECHR Ordinance 06.04.2000 "Case" Comingsoll SA "(Comingersoll SA) against Portugal” (Complaint N 35382/97). URL: http:// www.echr.coe.in. (in Russian).

8. Samorodov D.A. The Concept of Inviolability of Honor and Dignity in the Laws of the UK, France, USA, Germany and Russia. Bulletin of Moscow University named after S.Y. Witte. Series 2, Legal Sciences, 2016, no. 2 (9), pp. 40-47. (in Russian).

9. Sayapina E.N. On the Protection of Business Reputation. Current Issues of Accounting and Taxation, 2014, no. 4, pp. 10-15. (in Russian).

10. Rubenstein, Mitchel H. A Quick Look at the Defamation - Law. URL: https://www researchgate.net.

\section{Information about the Author}

Vladimir V. Yastrebov, Postgraduate Student, Department of Civil Law and Private International Law, Peoples' Friendship University of Russia, Miklukho-Maklay St., 6, 117198 Moscow, Russian Federation, vladimir-soin2012@yandex.ru, https://orcid.org/0000-0003-1729-6752

\section{Информация об авторе}

Владимир Валерьевич Ястребов, аспирант кафедры гражданского права и процесса и международного частного права, Российский университет дружбы народов, ул. Миклухо-Маклая, 6, 117198 г. Москва, Российская Федерация, vladimir-soin2012@yandex.ru, https://orcid.org/00000003-1729-6752 